\title{
Complementary and alternative medicine: attitudes, knowledge and use among surgeons and anaesthesiologists in Hungary
}

Sándor Árpád Soós ${ }^{1 *}$, Norbert Jeszenői ${ }^{2,3}$, Katalin Darvas $^{1,4}$ and László Harsányi ${ }^{1}$

\begin{abstract}
Background: Despite their worldwide popularity the question of using non-conventional treatments is a source of controversy among medical professionals. Although these methods may have potential benefits it presents a problem when patients use non-conventional treatments in the perioperative period without informing their attending physician about it and this may cause adverse events and complications. To prevent this, physicians need to have a profound knowledge about non-conventional treatments.
\end{abstract}

Methods: An anonymous questionnaire was distributed among surgeons and anaesthesiologists working in Hungarian university clinics and in selected city or county hospitals. Questionnaires were distributed by post, online or in person. Altogether 258 questionnaires were received from 22 clinical and hospital departments.

Results: Anaesthesiologists and surgeons use reflexology, Traditional Chinese Medicine, herbal medicine and manual therapy most frequently in their clinical practice. Traditional Chinese Medicine was considered to be the most scientifically sound method, while homeopathy was perceived as the least well-grounded method. Neural therapy was the least well-known method among our subjects.

Among the subjects of our survey only $3.1 \%$ of perioperative care physicians had some qualifications in nonconventional medicine, $12.4 \%$ considered themselves to be well-informed in this topic and $48.4 \%$ would like to study some complementary method. Women were significantly more interested in alternative treatments than men, $p=0.001427 ;$ OR: 2.2765 . Anaesthesiologists would be significantly more willing to learn non-conventional methods than surgeons. $86.4 \%$ of the participants thought that non-conventional treatments should be evaluated from the point of view of evidence. Both surgeons and anaesthesiologists accept the application of integrative medicine and they also approve of the idea of teaching these methods at universities.

Conclusions: According to perioperative care physicians, non-conventional methods should be evaluated based on evidence. They also expressed a willingness to learn about those treatments that meet the criteria of evidence and apply these in their clinical practice.

Keywords: Anaesthesiologist, Surgeon, CAM, Perioperative care, Integrative medicine

\footnotetext{
* Correspondence: soossandormd@gmail.com

${ }^{1}$ 1st Department of Surgery, Semmelweis University, Budapest, Hungary

Full list of author information is available at the end of the article
} 


\section{Background}

In recent decades, complementary and alternative medicine (CAM) has become increasingly popular. In the USA, the use of CAM rose from 33.8 to $42.1 \%$ from 1990 to 1997 among the total population [1], while in the 2000s this ratio was $34-37 \%$ [2, 3]. A recent systematic review of surveys in the UK indicated, $51.8 \%$ of the population applied alternative remedies at least once during their lifetime [4]. Among cancer patients the use of CAM grew from $25 \%$ in the 1970 s to $49 \%$ in the 2000s [5], and this rate can reach $61 \%$ among orthopaedic cancer patients [6]. In Canada, $27 \%$ of patients waiting for general surgery applied CAM [7], while in the USA the application ratio was 40-67\% [8, 9].

In Norway some forms of CAM treatment were available for patients in $50.5 \%$ of hospitals in 2008 and in $64.4 \%$ in 2013 [10]. Integrative medicine, which uses a holistic approach and CAM has grown popular not only among patients but also among medical professionals as it has gained more developed research basis [11].

The large-scale application of non-conventional treatments affect emergency care and the perioperative period [12]. Because of the risks of non-conventional treatments especially the potentially serious side-effects and drug interactions caused by herbal drugs, physicians working in perioperative care must be aware whether their patients apply CAM [13-15]. The situation regarding CAM methods is further complicated by the fact that if patients use them, they rarely inform their attending physician about it $[16,17]$. The main reasons for this are past negative experiences of patients or their fear of doctor preconceptions about CAM [18].

In view of the above, we conducted a survey of the attitudes and knowledge of Hungarian physicians, surgeons and anaesthesiologist working in perioperative care.

\section{Methods}

Our goal was to assess attitude of anaesthesiologists and surgeons towards CAM, their knowledge of particular treatments and to establish the extent to which they accept integrative medicine.

\section{Study design and data collection}

The survey was conducted via a questionnaire distributed online, by mail or in person among anaesthesiologists and surgeons working in Hungary. Our survey is a part of a complex study focusing on the relationship between perioperative care and CAM.

Previous publications were focused on the herb consumption of patients waiting for elective surgery [19] and the attitude of surgery patients towards CAM [20]. In the near future, we are going to survey the attitude towards CAM of healthcare professionals working in perioperative care as well.
In the survey 11 clinics from 4 Hungarian universities and other 11 surgery wards and intensive care departments participated. The questionnaire was not validated.

\section{Questionnaire}

The questionnaire consisted of four parts. The first part included socio-demographic data (age, gender, specialization, qualifications). In the second part, we enlisted those CAM methods that can be studied in Hungary and that were included in the 2010 position statement of the Hungarian Academy of Sciences. We used a table format to organize our data and we also examined how these methods were perceived by physicians [21]. In the third part, we explored those factors that influence subjects' attitudes towards CAM. In the fourth part, yes/no questions were used to address some issues regarding integrative medicine, such as its application, and training and teaching opportunities in this field. The English translation of the questionnaire is available in Additional file 1.

\section{Statistical analysis}

IBM SPSS 20.0 software (SPSS Inc., Chicago IL) was used to analyse data. We examined socio-demographic data using descriptive statistics. Independent-Samples T Test and Chi-squared test were applied to compare the opinion of anaesthesiologists and surgeons. Significant result was accepted as $p<0.05$.

\section{Results}

We processed 258 questionnaires: out of the 341 questionnaires we got 217 back in person or by mail (response rate $64 \%$ ) and 41 questionnaires were sent back to us online. Response ratio was not calculated for questionnaires received by mail as the number of physicians reached online was unknown (Additional file 2).

\section{Socio-demographic data}

Our subjects included 151 males and 107 females, with an average age of 39.9 years (24-71 years; SD 12.078). Table 1 shows the distribution of physicians based on their qualifications and specialization. 49 subjects (19\%) had at least another qualifying exam. Eight subjects (3.1\%) had qualifications in naturopathy: 1 surgeon and 7 anaesthesiologists.

Almost half of the responses were from the capital city, Budapest (49.2\%) (Table 2).

\section{Evaluation of the treatments}

The evaluation of individual treatments is presented in Table 3. The least known method was neural therapy (213 subjects; $82.6 \%$ ). The method considered to be the least scientifically well-grounded was homeopathy (161 subjects; $62.4 \%$ ), while Traditional Chinese Medicine (TCM, 149 subjects; $57.8 \%$ ) and manual therapy (84 
Table 1 Qualifications, gender distribution and specialisation of the physicians

\begin{tabular}{|c|c|c|c|c|}
\hline & & Surgeon $(n=83)$ & Anaesthesiologist $(n=175)$ & Total ( $n$ and \%) \\
\hline \multirow[t]{3}{*}{ Qualifications } & Post-secondary degree & 21 & 5 & $26(10.0)$ \\
\hline & Specialist & 41 & 102 & $143(55.5)$ \\
\hline & Resident & 21 & 68 & $89(34.5)$ \\
\hline \multirow[t]{2}{*}{ Gender } & Male & 71 & 80 & $151(58.5)$ \\
\hline & Female & 12 & 95 & $107(41.5)$ \\
\hline \multirow[t]{2}{*}{ Has other specialist qualifications? } & Yes & 23 & 26 & $49(19.0)$ \\
\hline & No & 60 & 149 & $209(81.0)$ \\
\hline
\end{tabular}

subjects, $32.6 \%$ ) were perceived as the most scientifically acceptable treatments. The most frequently recommended methods were herbal medicine/phytotherapy (26 subjects, $10.1 \%$ ), TCM and manual therapy (22-22 subjects; 8.5-8.5\%), while reflexology resulted to be the most frequently applied method (6 subjects; $2.3 \%$ ). Anaesthesiologists recommended or applied TCM significantly more often than surgeons, $p=0.017555$; OR: 4.0351 (95 \% CI 1.1756-13.8496).

\section{Attitudes towards CAM methods}

Table 4 shows the extent to which subjects' opinion about CAM was influenced by different factors. The most important factor was evidence, while the least important factor was the media. There was no significant difference between surgeons and anaesthesiologists in the evaluation of the factors listed.

Table 5 shows attitudes towards CAM. No significant difference was found between the surgeons and anaesthesiologists, using the Independent-Samples $\mathrm{T}$ Test, 0.247; results were similar both in terms of

Table 2 Geographic distribution of respondents

\begin{tabular}{llll}
\hline County & $\begin{array}{l}\text { Surgeon } \\
(n=83)\end{array}$ & $\begin{array}{l}\text { Anaesthesiologist } \\
(n=175)\end{array}$ & $\begin{array}{l}\text { Total } \\
(n \text { and \%) }\end{array}$ \\
\hline Budapest (capital) & 61 & 66 & $127(49.2)$ \\
Bács-Kiskun & 7 & 12 & $19(7.4)$ \\
Baranya & 0 & 1 & $1(0.4)$ \\
Borsod-Abaúj-Zemplén & 0 & 20 & $20(7.8)$ \\
Csongrád & 0 & 4 & $4(1.6)$ \\
Győr-Moson-Sopron & 4 & 1 & $5(2.0)$ \\
Hajdú-Bihar & 0 & 17 & $17(6.5)$ \\
Heves & 1 & 0 & $1(0.4)$ \\
Komárom-Esztergom & 9 & 5 & $14(5.4)$ \\
Pest & 1 & 11 & $12(4.6)$ \\
Szabolcs-Szatmár & 0 & 22 & $22(8.5)$ \\
Veszprém & 0 & 1 & $1(0.4)$ \\
Zala & 0 & 15 & $15(5.8)$ \\
\hline
\end{tabular}

interest $(p=0.462433)$, and in rejection $(p=0.177313)$. As for gender differences, the interest in CAM was significantly higher among women, $p=0.001427$; OR: 2.2765 (95 \% CI: 1.3674-3.7901), while the number of those who have a negative attitude towards these methods was significantly higher among men, $p=0.001015$; OR: 4.6439 (95 \% CI: 1.7305-12.4619).

Perioperative physicians attitudes towards CAM with respect to age groups are shown in Fig. 1. In terms of interest no significant differences were found among the groups.

\section{Training and teaching possibilities in CAM and the application of integrative medicine}

Further pragmatic aspects of the study can be seen in Table 6 (use of CAM, knowledge of this topic, education, acquisition, application, integrative treatment, reimbursement). $36 \%$ (93 subjects) claimed to have used CAM in the case of their own illness or that of a family member. However, only $12.4 \%$ (32 subjects) claimed to have enough knowledge about these methods. Almost half of the subjects would like to learn some CAM method, with anaesthesiologists being significantly more interested in this than surgeons, $p=0.000425$; OR: 2.6397 (95\% CI 1.5265-4.5648). 6 surgeons and 12 anaesthesiologists, altogether 18 physicians (7 \%) applies CAM in clinical practice.

Two-thirds of participant supported the concept of integrative medicine and in this aspect, no significant differences was found, $p=0.232$.

A significantly higher number of anaesthesiologists than surgeons supported the idea that CAM should be an integral part of modern medicine in terms of reimbursement, accessible via the public healthcare system in Hungary, $p=0.007708$; OR: 2.0798 (95 \% CI 1.20833.58). $73.6 \%$ (190 subjects) think that training in CAM should be completed within the frameworks of education at medical universities. This was considered to be important both by surgeons and anaesthesiologists, there were no significant differences between the two groups in this aspect, $p=0.522$. 
Table 3 Attitudes towards surveyed CAM methods

\begin{tabular}{|c|c|c|c|c|c|c|}
\hline & Specialization & $\begin{array}{l}\text { Does not know } \\
\text { it ( } n \text { and \%) }\end{array}$ & $\begin{array}{l}\text { Does not consider it } \\
\text { to be scientifically } \\
\text { well-grounded ( } n \text { and \%) }\end{array}$ & $\begin{array}{l}\text { Considers it to be scientifically } \\
\text { well-grounded ( } n \text { and \%) }\end{array}$ & $\begin{array}{l}\text { Recommends it to } \\
\text { patients ( } n \text { and \%) }\end{array}$ & $\begin{array}{l}\text { Applies it } \\
\text { ( } n \text { and \%) }\end{array}$ \\
\hline \multirow[t]{3}{*}{$\overline{T C M}$} & Surgeon & $16(19)$. & $14(16.9)$ & $50(60.2)$ & $3(3.6)$ & $0(0.0)$ \\
\hline & Anaesthesiologist & $33(18.9)$ & $20(11.4)$ & 99 (56.6) & 19 (10.8) & $4(2.3)$ \\
\hline & Total & $49(19.0)$ & $34(13.2)$ & $149(57.8)$ & $22(8.5)$ & $4(1.5)$ \\
\hline \multirow[t]{3}{*}{ Homeopathy } & Surgeon & $11(13.2)$ & $57(68.7)$ & $15(18.1)$ & $0(0.0)$ & $0(0.0)$ \\
\hline & Anaesthesiologist & $27(15.4)$ & $104(59.4)$ & $31(17.7)$ & $12(6.9)$ & $1(0.6)$ \\
\hline & Total & $38(14.7)$ & $161(62.4)$ & $46(17.8)$ & $12(4.7)$ & $1(0.4)$ \\
\hline \multirow[t]{3}{*}{ Herbal medicine } & Surgeon & $34(41.0)$ & $17(20.5)$ & $21(25.3)$ & $9(10.8)$ & $2(2.4)$ \\
\hline & Anaesthesiologist & $84(48.0)$ & $20(11.4)$ & $54(30.9)$ & $17(9.7)$ & $0(0.0)$ \\
\hline & Total & $118(45.7)$ & $37(14.3)$ & $75(29.1)$ & $26(10.1)$ & $2(0.2)$ \\
\hline \multirow[t]{3}{*}{ Manual therapy } & Surgeon & $33(39.8)$ & $18(21.7)$ & $27(32.5)$ & $5(6.0)$ & $0(0.0)$ \\
\hline & Anaesthesiologist & $86(49.1)$ & $14(8.0)$ & $57(32.6)$ & $17(9.7)$ & $1(0.6)$ \\
\hline & Total & $119(46.1)$ & $32(12.4)$ & 84 (32.6) & $22(8.5)$ & $1(0.4)$ \\
\hline \multirow[t]{3}{*}{ Neural therapy } & Surgeon & $69(83.2)$ & $8(9.6)$ & $4(4.8)$ & $2(2.4)$ & $0(0.0)$ \\
\hline & Anaesthesiologist & $144(82.3)$ & $13(7.4)$ & $14(8.0)$ & $3(1.7)$ & $1(0.6)$ \\
\hline & Total & $213(82.6)$ & $21(8.1)$ & $18(7.0)$ & $5(1.9)$ & $1(0.4)$ \\
\hline \multirow[t]{3}{*}{ Reflexology } & Surgeon & $38(45.8)$ & $22(26.5)$ & $17(20.5)$ & $5(6.0)$ & $1(1.2)$ \\
\hline & Anaesthesiologist & $82(46.8)$ & $34(19.4)$ & $46(26.3)$ & $8(4.6)$ & $5(2.9)$ \\
\hline & Total & $120(46.5)$ & $56(21.7)$ & $63(24.4)$ & $13(5.1)$ & $6(2.3)$ \\
\hline \multirow[t]{3}{*}{ Bioenergetic medicine } & Surgeon & $40(48.2)$ & $39(47)$ & $4(4.8)$ & $0(0.0)$ & $0(0.0)$ \\
\hline & Anaesthesiologist & $94(53.7)$ & $62(35.4)$ & $15(8.6)$ & $4(2.3)$ & $0(0.0)$ \\
\hline & Total & $134(51.9)$ & $101(39.2)$ & $19(7.4)$ & $4(1.5)$ & $0(0.0)$ \\
\hline \multirow[t]{3}{*}{ Kinesiology } & Surgeon & $37(44.6)$ & $30(36.1)$ & $10(12.1)$ & $6(7.2)$ & $0(0.0)$ \\
\hline & Anaesthesiologist & $93(53.1)$ & $35(20.0)$ & 36 (20.6) & $11(6.3)$ & $0(0.0)$ \\
\hline & Total & $130(50.4)$ & 65 (25.2) & $46(17.8)$ & $17(6.6)$ & $0(0.0)$ \\
\hline
\end{tabular}

\section{Discussion}

\section{Use of CAM in clinical practice}

Our primary aim was to measure how frequently CAM is used by perioperative physicians in Hungary. Surveys concerning the attitude towards CAM among surgeons and anaesthesiologists were not found. Conducted studies emphasize on family physicians or physicians working on other fields. In England, $32 \%$ of hospital physicians have already used CAM in their practice [22], this ratio is $24 \%$ in the USA and $58 \%$ in India [23, 24]. In Germany $31 \%$ of orthopaedic surgeons, $23 \%$ of family physicians and $6 \%$ of internists apply CAM [25]. In our survey, 18 surgeons and anaesthesiologists (7\%) claimed to use CAM: this number is much lower than the average rate of CAM-usage among hospital physicians, as can be found in the corresponding literature.

\section{Attitude and predictors}

Our survey examined the acceptance of CAM and its predictors. CAM is applied by a well-defined group: among the patients significantly more females, with high income and education use CAM, and application increases with serious clinical conditions [26, 27]. However, predictors of physicians applying or recommending CAM were seldom analysed. According to a recently published Polish survey, eldery physicians were more positive towards CAM than their younger colleagues. [28]. According to a German survey, $51 \%$ of physicians were in favor of CAM use in clinical practice: it is not influenced by the age or the gender of the physicians. However, compared to other physicians, family physicians are more likely to apply CAM [29]. In our survey, more than half of the participants $(52.7 \%)$ expressed interest. Two main factors influencing their opinion were identified. Though only 32 physicians (12\%) have enough knowledge about CAM, scientific evidence was cited by $86 \%$ of the participants as significantly influential. Personal experience was an important factor too as 93 physicians (36\%) have used CAM for their own or family member's illness. Women showed significantly 
Table 4 Factors influencing attitudes towards CAM

\begin{tabular}{|c|c|c|c|c|}
\hline & Specialization & Significant influence ( $n$ and \%) & Moderate influence ( $n$ and \%) & No influence ( $n$ and \%, \\
\hline \multirow[t]{3}{*}{ Evidence } & Surgeon & $75(90.4)$ & $6(7.2)$ & $2(2.4)$ \\
\hline & Anaesthesiologist & $148(84.6)$ & $21(12.0)$ & $6(3.4)$ \\
\hline & Total & $223(86.4)$ & $27(10.5)$ & $8(3.1)$ \\
\hline \multirow[t]{3}{*}{ Colleagues' opinion } & Surgeon & $25(30.1)$ & $44(53.0)$ & $14(16.9)$ \\
\hline & Anaesthesiologist & $58(33.1)$ & $85(48.6)$ & $32(18.3)$ \\
\hline & Total & $83(32.2)$ & $129(50)$ & 46 17.8) \\
\hline \multirow{3}{*}{$\begin{array}{l}\text { Personal experience (own or } \\
\text { that of a family member) }\end{array}$} & Surgeon & $39(47.0)$ & $27(32.5)$ & $17(20.5)$ \\
\hline & Anaesthesiologist & $91(52.0)$ & $59(33.7)$ & $25(14.3)$ \\
\hline & Total & $130(50.4)$ & $86(33.3)$ & $42(16.3)$ \\
\hline \multirow[t]{3}{*}{ Media } & Surgeon & $1(1.2)$ & $17(20.5)$ & $65(78.3)$ \\
\hline & Anaesthesiologist & $4(2.3)$ & $36(20.6)$ & $135(77.1)$ \\
\hline & Total & $5(1.9)$ & $53(20.6)$ & $200(77.5)$ \\
\hline \multirow[t]{3}{*}{ More training opportunities } & Surgeon & $20(24.1)$ & $40(48.2)$ & $23(27.7)$ \\
\hline & Anaesthesiologist & $54(30.9)$ & $77(44.0)$ & $44(25.1)$ \\
\hline & Total & $74(28.7)$ & $117(45.3)$ & $67(26.0)$ \\
\hline \multirow[t]{3}{*}{ Eligibility for reimbursement } & Surgeon & $6(7.2)$ & $34(41.0)$ & $43(51.8)$ \\
\hline & Anaesthesiologist & $24(13.7)$ & $66(37.7)$ & 85 (48.6) \\
\hline & Total & $30(11.6)$ & $100(38.8)$ & $128(49.6)$ \\
\hline
\end{tabular}

more interest than men, similarly to patients. Attitudes towards CAM were not influenced by age, and no significant differences were found between surgeons and anaesthesiologists.

\section{The evaluation of individual methods}

The acceptance of CAM methods was also examined in the survey. In an Italian study, $8 \%$ of those surveyed physicians use CAM and the most widely accepted methods are homeopathy, TCM, phytotherapy and manual therapy. These physicians are specialized in musculoskeletal apparatus or anaesthesiology [30]. A survey in Torino found that $84.2 \%$ of primary care physicians consider TCM to be a scientifically wellbased method and $6 \%$ apply it in practice [31]. According to German, English and Swiss surveys carried out amongst family physicians, the most widely accepted methods are TCM, manual therapy, homeopathy, phytotherapy and neural therapy [32-34]. In our study we found that the most popular methods include TCM, herbal medicine/phytotherapy, manual therapy and reflexology, while homeopathy is the most controversial and neural therapy the least known method.

\section{Willingness to learn}

Surveying the willingness to learn CAM methods is crucial as it represents openness and positivity towards CAM. As far as training opportunities in CAM methods are concerned, $55.8 \%$ of healthcare professionals would like to learn about CAM according to a Swedish survey [35], while in England this number is $56 \%$ [36]. In Hungary $56.7 \%$ of family physicians would like to study CAM [37]. Our own findings reveal that $48.4 \%$ of those surveyed would like to learn CAM: $32.5 \%$ of surgeons and $56.0 \%$ of anaesthesiologists, which is a significant difference. Thus similar trends observed in other countries can be observed in Hungary as well, anaesthesiologists have shown more openness towards CAM than surgeons. $73.6 \%$ of our

Table 5 Evaluation of attitude towards CAM with respect to specialization and gender

\begin{tabular}{llll}
\hline & Interested $(n$ and \%) & Indifferent $(n$ and \%) & Negative $(n$ and \%) \\
\hline Surgeon $(n=83)$ & $41(49.4)$ & $28(33.7)$ & $14(16.9)$ \\
Anaesthesiologist $(n=175)$ & $95(54.3)$ & $61(34.8)$ & $19(10.9)$ \\
Male $(n=151)$ & $67(44.4)$ & $56(37.1)$ & $28(18.5)$ \\
Female $(n=107)$ & $69(64.5)$ & $33(30.8)$ & $5(4.7)$ \\
\hline
\end{tabular}




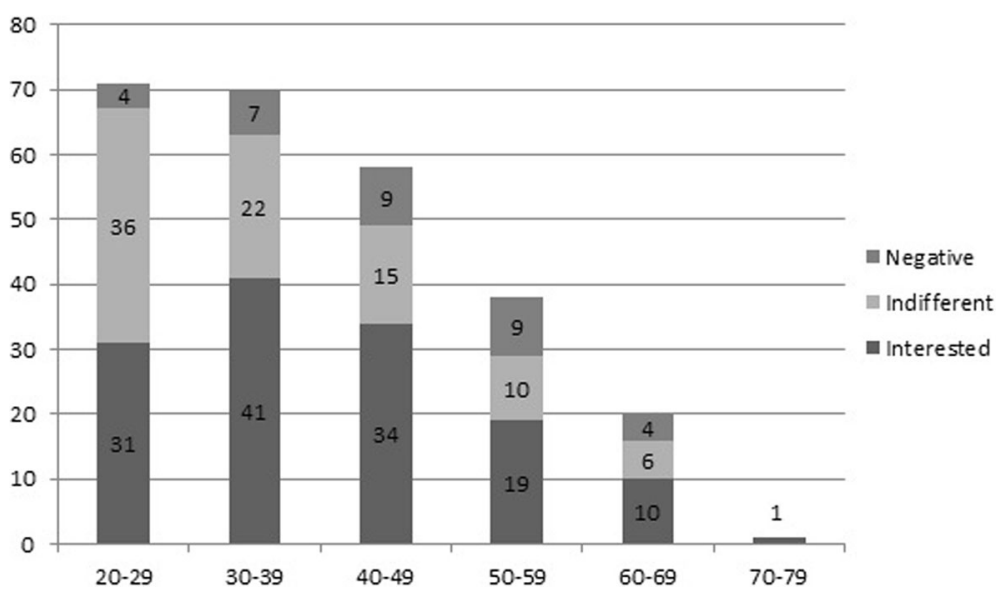

Fig. 1 Attitudes towards CAM with respect to age

subjects considers it to be important that these methods should be taught in university settings.

\section{Integrative medicine}

Integrative medicine - the combined use of modern and alternative treatments - is becoming more widespread within primary care [38], gynaecology [39], palliative medicine [40], oncology [41]. In an Italian survey, $58 \%$ of primary care physicians advised their patients to use CAM [42], while in a Russian survey, $100 \%$ of physicians may recommend these treatments [43]. Some suggest that it would be useful if physicians could acquire this new approach as part of their training $[44,45]$. In our survey, two-thirds of surgeons and anaesthesiologists supported

Table 6 The use of CAM, evaluation of knowledge, integration into education and reimbursment

\begin{tabular}{|c|c|c|c|c|c|}
\hline & Specialization & Yes ( $n$ and \%) & No ( $n$ and \%) & Independent-Samples T Test (t) & Pearson $(p)$ \\
\hline \multirow[t]{3}{*}{ Uses CAM for their own or family member's illnes } & Surgeon & $25(30.1)$ & $58(69.9)$ & 1.393 & 0.165 \\
\hline & Anaesthesiologist & $68(38.9)$ & $107(61.1)$ & & \\
\hline & Total & $93(36.0)$ & $165(64.0)$ & & \\
\hline \multirow[t]{3}{*}{ Has enough knowledge about CAM } & Surgeon & $13(15.7)$ & $70(84.3)$ & -1.032 & 0.304 \\
\hline & Anaesthesiologist & $19(10.9)$ & $156(89.1)$ & & \\
\hline & Total & $32(12.4)$ & $226(87.6)$ & & \\
\hline \multirow[t]{3}{*}{ Would like to learn about CAM } & Surgeon & $27(32.5)$ & $56(67.5)$ & 3.669 & 0.000425 \\
\hline & Anaesthesiologist & $98(56.0)$ & $77(44.0)$ & & \\
\hline & Total & $125(48.4)$ & $133(51.6)$ & & \\
\hline \multirow[t]{3}{*}{ CAM should be taught at universities } & Surgeon & $59(71.1)$ & $24(28.9)$ & 0.641 & 0.522 \\
\hline & Anaesthesiologist & $131(74.9)$ & $44(25.1)$ & & \\
\hline & Total & $190(73.6)$ & $68(26.4)$ & & \\
\hline \multirow[t]{3}{*}{ Applies CAM in clinical practice } & Surgeon & $6(7.2)$ & $77(92.8)$ & -0.109 & 0.913 \\
\hline & Anaesthesiologist & $12(6.9)$ & $163(93.1)$ & & \\
\hline & Total & $18(7.0)$ & $240(93.0)$ & & \\
\hline \multirow[t]{3}{*}{ Integrative treatment } & Surgeon & $51(61.4)$ & $32(38.6)$ & 1.200 & 0.232 \\
\hline & Anaesthesiologist & $121(69.1)$ & $54(30.9)$ & & \\
\hline & Total & $172(66.7)$ & $86(33.3)$ & & \\
\hline \multirow[t]{3}{*}{ Integrated reimbursement } & Surgeon & $28(33.7)$ & $55(66.3)$ & 2.743 & 0.007708 \\
\hline & Anaesthesiologist & $90(51.4)$ & 85 (48.6) & & \\
\hline & Total & $118(45.7)$ & $140(54.3)$ & & \\
\hline
\end{tabular}


the introduction of integrative medicine. The issue of financial support was considered to be significantly more important by anaesthesiologists.

\section{Conclusions}

Our survey was aimed at the assessment of surgeons' and anaesthesiologists' attitude towards CAM methods and their application, instruction and integration. Even though, compared with other specializations, the rate of CAM qualifications is low in the examined group of physicians, our results reveal that perioperative care physicians find the application of evidence-based CAM methods acceptable both in their private life and in their clinical practice.

\section{Additional files}

Additional file 1: The English translation of the questionnaire. (DOCX $18 \mathrm{~kb}$ )

Additional file 2: List of hospitals participated in the survey. (DOCX $19 \mathrm{~kb}$ )

\section{Abbreviations}

CAM: Complementary and Alternative Medicine; Cl: Confidence interval; OR: Odds ratio; TCM: Traditional Chinese Medicine

\section{Acknowledgements}

The authors acknowledge Dóra Hámori for fruitful discussions and for carefully reading the manuscript. Anthony Prior is acknowledged for careful language editing.

\section{Funding}

The work was partially supported by the Hungarian Scientific Research Fund (OTKA K112807).

\section{Availability of data and material}

All data generated or analysed during this study are included in this published article. The datasets used and analysed during the current study available from the corresponding author on reasonable request.

\section{Authors' contributions}

SAS conceived the study, designed the questionnaire, conducted the analysis and was involved in the writing of the manuscript. NJ was involved in the analysis of data and writing the manuscript. KD and LH were involved in the collection of data and the writing of the manuscript. All authors read and approved the final manuscript.

\section{Competing interests}

The authors declare that they have no competing interests.

\section{Consent for publication}

Not applicable.

\section{Ethics approval and consent to participate}

The research was in line with the principles of the Helsinki Declaration and was authorized by Semmelweis University Regional And Institutional Committee Of Science And Research Ethics (SE TUKEB 142/2015).

\section{Author details}

${ }^{1} 1$ st Department of Surgery, Semmelweis University, Budapest, Hungary. ${ }^{2}$ MTA NAP-B Molecular Neuroendocrinology Group, Institute of Physiology, Szentágothai Research Centre, Centre for Neuroscience, University of Pécs, Pécs, Hungary. ${ }^{3}$ Department of Genetics, Eötvös Loránd University, Budapest, Hungary. ${ }^{4}$ Department of Anaesthesiology and Intensive Therapy, Semmelweis University, Budapest, Hungary.
Received: 27 November 2015 Accepted: 1 November 2016

Published online: 08 November 2016

\section{References}

1. Eisenberg DM, Davis RB, Ettner SL, Appel S, Wilkey S, Van Rompay M, et al. Trends in alternative medicine use in the United States, 1990-1997: results of a follow-up national survey. JAMA. 1998:280:1569-75.

2. Clarke T, Black L, Stussman B, Barnes PM, Nahin RL. Trends in the use of complementary health approaches among adults: United States, 2002-2012. Natl Health Stat Report. 2015;79:1-16.

3. Nguyen LT, Davis RB, Kaptchuk TJ, Phillips RS. Use of complementary and alternative medicine and self-rated health status: results from a national survey. J Gen Intern Med. 2011;26(4):399-404. doi:10.1007/ s11606-010-1542-3

4. Posadzki P, Watson LK, Alotaibi A, Ernst E. Prevalence of use of complementary and alternative medicine (CAM) bypatients/consumers in the UK: systematic review of surveys. Clin Med. 2013;13(2):126-31. doi:10.7861/clinmedicine.13-2-126.

5. Horneber M, Bueschel G, Dennert G, Less D, Ritter E, Zwahlen M. How many cancer patients use complementary and alternative medicine: A systematic review and metaanalysis. Integr Cancer Ther. 2012;1:187-203.

6. Dhanoa A, Yong TL, Yeap SJ, Lee IS, Singh VA. Complementary and alternative medicine use amongst Malaysian orthopaedic oncology patients. BMC Complement Altern Med. 2014;14:404. doi:10.1186/1472-6882-14-404.

7. Schieman C, Rudmik LR, Dixon E, Sutherland F, Bathe OF. Complementary and alternative medicine use among general surgery, hepatobiliary surgery and surgical oncology patients. Can J Surg. 2009;52(5):422-6.

8. Norred CL. Complementary and alternative medicine use by surgical patients. ORN J. 2002;7(6):1013-21.

9. Norred CL, Zamudio S, Palmer SK. Use of complementary and alternative medicines by surgical patients. AANA J. 2000;68:13-8.

10. Jacobsen R, Fønnebø VM, Foss N, Kristoffersen AE. Use of complementary and alternative medicine within Norwegian hospitals. BMC Complement Altern Med. 2015;15:275. doi:10.1186/s12906-015-0782-5.

11. Coulter ID, Khorsan R, Crawford C, Hsiao AF. Integrative health care under review: an emerging field. J Manipulative Physiol Ther. 2010;33:690-710.

12. Waterbrook AL, Southall JC, Strout TD, Baumann MR. The knowledge and usage of complementary and alternative medicine by emergency department patients and physicians. J Emerg Med. 2010;39(5):569-75. doi:10.1016/j.jemermed.2008.01.007.

13. Skinner CM, Rangasami J. Preoperative use of herbal medicines: a patient survey. Br J Anaesth. 2002;89(5):792-5.

14. Tsen LC, Segal S, Pothier M, Bader AM. Alternative medicine use in presurgical patient. Anesthesiology. 2000;93(1):148-51.

15. Kaye AD, Clarke RC, Sabar R, Vig S, Dhawan KP, Hofbauer R, et al. Herbal medicines: current trends in anesthesiology practice - a hospital survey. J Clin Anesth. 2000;12(6):468-71.

16. Leung JM, Dzankic S, Manku K, Yuan S. The prevalence and predictors of the use of alternative medicine in presurgical patients in 5 California hospitals. Anes Analg. 2001;93:1062-8.

17. Shakeel M, Bruce J, Jehan S, McAdam TK, Bruce DM. Use of Complementary and Alternative Medicine by Patients Admittedto a Surgical Unit in Scotland. Ann R Coll Surg Engl. 2008;90(7):571-6.

18. Robinson A, McGrail MR. Disclosure of CAM use to medical practitioners: a review of qualitative and quantitative studies. Complement Ther Med. 2004; 12:90-8.

19. Soós SÁ, Jeszenői N, Darvas K, Harsányi L. Herbal medicine use by surgery patients in Hungary: a descriptive study. BMC Complement Altern Med. 2015;15:358. doi:10.1186/s12906-015-0890-2.

20. Soós SÁ, Jeszenői N, Darvas K, Harsányi L. Complementary and alternative medicine use by surgery patients in Hungary. [Nem-konvencionális gyógymódok használata sebészeti betegek között]. Orv Hetil. 2016;157(37): 1483-8. doi:10.1556/650.2016.30543 [Hungarian].

21. Dobozy A, Kerpel-Fronius S, Komoly S, Kovács LG, Mandl J, Muszbek L, et al. Complementary therapies - based on the principles of evidence-based medicine. Positionstatement of the Medical Sciences Section of the Hungarian Academy of Sciences. Orv Hetil. 2011;152:1197-204 [Hungarian].

22. Lewith GT, Hyland M, Gray SF. Attitudes to and use of complementary medicine among physicians in the United Kingdom. Complement Ther Med. 2001;9:167-72. 
23. Corbin Winslow L, Shapiro H. Physicians want education about complementary and alternative medicine to enhance communication with their patients. Arch Intern Med. 2002;162:1176-81.

24. Roy V, Gupta M, Ghosh RK. Perception, attitude and usage of complementary and alternative medicine among doctors and patients in a tertiary care hospital in India. Indian J Pharma. 2015:47:137-42.

25. Linde K, Alscher A, Friedrichs C, Wagenpfeil S, Karsch-Völk M, Schneider A. Belief in an duse of complementary therapies among family physicians, internists and orthopaedists in Germany - cross-sectional survey. Fam Pract. 2015;32:62-8.

26. $\mathrm{Ni} \mathrm{H}$, Simile $\mathrm{C}$, Hardy AM. Utilization of complementary and alternative medicine by United States adults: results from the 1999 national health interview survey. Med Care. 2002;40(4):353-8.

27. Reid R, Steel A, Wardle J, Trubody A, Adams J. Complementary medicine use by the Australian population: a critical mixed studies systematic review of utilisation, perceptions and factors associated with use. BMC Complement Altern Med. 2016:16:176. doi:10.1186/s12906-016-1143-8.

28. Olchowska-Kotala A, Barański J. Polish physicians' attitudes to complementary and alternative medicine. Complement Ther Med. 2016;27: 51-7. doi:10.1016/j.ctim.2016.05.004.

29. Stange R, Amhof R, Moebus S. Complementary and alternative medicine: attitudes and patterns of use by German physicians in a national survey. J Altern Complement Med. 2008;14:1255-61. doi:10.1089/acm.2008.0306.

30. Cocconi G, Caminiti C, Capriglia S, Gennari M, Minari R, Schianchi P, d'Aloia T, et al. Attitudes to, and practice of, unconventional medicine by physicians in Italy. Eur J Intern Med. 2006;17:32-7.

31. Fanì M, Maestro $M$, Mandas $A$, Orecchia $S$, Le Gouëllec $L$, Pedrali T. What do general practitioners think about acupuncture? Ann Ig. 2014;26:213-8. doi:10.7416/ai.2014.1979

32. Schmidt K, Jacobs PA, Barton A. Cross-cultural differences in GPs' attitudes towards complementary and alternative medicine: A survey comparing regions of the UK and Germany. Complement Ther Med. 2002;10:141-7.

33. Joos S, Musselmann B, Szecsenyi J. Integration of complementary and alternative medicine into family practices in Germany: Results of a national survey. Evid Based Complement Alternat Med. 2011;2011:495813. doi:10.1093/ecam/nep019.

34. Déglon-Fischer A, Barth J, Ausfeld-Hafter B. Complementary and alternative medicine in primary care in Switzerland. Komplementärmedizin in schweizer praxen der grundversorgung. 2009;16:251-5.

35. Bjerså K, Stener Victorin E, Fagevik Olsén M. Knowledge about complementary, alternative and integrative medicine (CAM) among registered health care providers in Swedish surgical care: a national survey among university hospitals. BMC Complement Altern Med. 2012;12:42.

36. van Haselen RA, Reiber U, Nickel I, Jakob A, Fisher PA. Providing complementary and alternative medicine in primary care: The primary care workers' perspective. Complement Ther Med. 2004;12(1):6-16.

37. Soós SÁ, Eőry A, Eőry A, Harsányi L, Kalabay L. Complementary and alternative medicine in the primary care physicians' viewpoint. [Nemkonvencionális gyógymódok a háziorvosszemszögéből]. Orv Hetil. 2015; 156:1133-9. doi:10.1556/650.2015.30132 [Hungarian].

38. Sundberg T, Halpin J, Warenmark A, Falkenberg T. Towards a model for integrative medicine in Swedish primary care. BMC Health Serv Res. 2007;7:107.

39. Lai JN, Chen PC, Wang JD, Wu TC, Chung V. Integrative Gynecology and Women's Healthcare. Evid Based Complement Alternat Med. 2015;2015: 852615. doi:10.1155/2015/852615.

40. Marchand L. Integrative and complementary therapies for patients with advanced cancer. Ann Palliat Med. 2014;3:160-71. doi:10.3978/j.issn.22245820.2014.07.01.

41. Ramamoorthy A, Janardhanan S, Jeevakarunyam S, Jeddy N, Eagappan S. Integrative Oncology in Indian Subcontinent: An Overview. J Clin Diagn Res. 2015;9:XE01-3. doi:10.7860/JCDR/2015/12185.5714.

42. Giannelli M, Cuttini M, Da Frè M, Buiatti E. General practitioners' knowledge and practice of complementary/alternative medicine and its relationship with life-styles: A population-based survey in Italy. BMC Fam Pract. 2007;8: 30. doi:10.1186/1471-2296-8-30.

43. Brown S. Use of complementary and alternative medicine by physicians in St. Petersburg, Russia. J Altern Complement Med. 2008;14:9. doi:10.1089/ acm.2007.7126.
44. Kligler B, Koithan M, Maizes V, Hayes M, Schneider C, Lebensohn P, et al Competency-based evaluation tools for integrative medicine training in family medicine residency: a pilot study. BMC Med Educ. 2007;7:7.

45. Lebensohn P, Dodds S, Brooks AJ, Cook P, Guerrera M, Sierpina V, et al. Increasing resident recruitment into family medicine: effect of a unique curriculum in integrative medicine. Explore (NY). 2014;10:187-92. doi:10.1016/j.explore.2014.02.001.

\section{Submit your next manuscript to BioMed Central and we will help you at every step:}

- We accept pre-submission inquiries

- Our selector tool helps you to find the most relevant journal

- We provide round the clock customer support

- Convenient online submission

- Thorough peer review

- Inclusion in PubMed and all major indexing services

- Maximum visibility for your research

Submit your manuscript at www.biomedcentral.com/submit
Biomed Central 